\title{
Postprandial glycemia in healthy subjects: Which probiotic dairy food is more adequate?
}

\author{
L. C. Grom, ${ }^{1}$ R. S. Rocha, ${ }^{1,2}$ C. F. Balthazar, ${ }^{2}$ J. T. Guimarães, ${ }^{2}$ N. M. Coutinho, ${ }^{2}$ C. P. Barros, ${ }^{2}$ T. C. Pimentel, ${ }^{3}$ \\ E. L. Venâncio, ${ }^{4}$ I. Collopy Junior, ${ }^{4}$ P. M. C. Maciel, ${ }^{4}$ P. H. F. Silva, ${ }^{5}$ D. Granato, ${ }^{6}$ M. Q. Freitas, ${ }^{2}$ E. A. Esmerino, ${ }^{2}$ \\ M. C. Silva, ${ }^{1}$ and A. G. Cruz ${ }^{1 *}$ \\ ${ }^{1}$ Departamento de Alimentos, Instituto Federal de Educação, Ciência e Tecnologia do Rio de Janeiro (IFRJ), 20270-021, Rio de Janeiro, Brazil \\ ${ }^{2}$ Faculdade de Medicina Veterinária, Universidade Federal Fluminense (UFF), 24230-340, Niterói, Brazil \\ ${ }^{3}$ Instituto Federal do Paraná (IFPR), Paranavaí, 87703-536, Paraná, Brazil \\ ${ }^{4}$ Departamento de Farmácia, Instituto Federal de Educação, Ciência e Tecnologia do Rio de Janeiro (IFRJ), 21715-000, Rio de Janeiro, Brazil \\ ${ }^{5}$ Departamento de Nutrição, Universidade Federal de Juiz de Fora (UFJF), 36036-330, Juiz de Fora, Brazil \\ ${ }^{6}$ Innovative Food System, Production Systems Unit, Natural Resources Institute Finland (LUKE), Innovation Open House, Maarintie 6, \\ FI-02150 Espoo, Finland
}

\begin{abstract}
The consumption of probiotic-enriched dairy products has been associated with many health benefits, including anti-hyperglycemic activity. The effect on health is dependent on the type of probiotic culture used and the dairy product consumed. This study evaluated the effect of different probiotic-enriched dairy matrices (Minas Frescal cheese, Prato cheese, and whey dairy beverage) containing Lactobacillus casei on in vitro and in vivo anti-hyperglycemic activity. For this purpose, in vitro anti-hyperglycemic activity was determined by the inhibition of $\alpha$-glucosidase and $\alpha$-amylase activities, and a human study was performed with healthy individuals $(\mathrm{n}=15$, consumption of bread as a control; bread + Minas Frescal cheese; bread + Prato cheese; bread + dairy beverage) to assess the effects of different probiotic foods on postprandial glycemia. In vitro data showed that Prato cheese presented the highest lipid $(36.9 \mathrm{~g} / 100 \mathrm{~g})$ and protein $(26.5 \mathrm{~g} / 100 \mathrm{~g})$ contents as well as the highest $\alpha$-amylase $(60.7 \%)$ and $\alpha$-glucosidase $(52.6 \%)$ inhibition. The consumption of Prato cheese resulted in a lesser increase in blood glucose level $(13 \mathrm{mg} / \mathrm{dL})$ compared with the consumption of bread alone $(19 \mathrm{mg} / \mathrm{dL})$, Minas Frescal cheese (20 $\mathrm{mg} / \mathrm{dL})$, and whey dairy beverage $(30 \mathrm{mg} / \mathrm{dL})$, with glycemic indices similar to that observed for the control. The present results demonstrated a good correlation between in vitro and in vivo data, in which the type of dairy matrix affects the anti-hyperglycemic activity. It
\end{abstract}

Received August 4, 2019.

Accepted October 7, 2019.

*Corresponding author: food@globo.com is concluded that the consumption of probiotic Prato cheese can contribute to the reduction of postprandial glycemia in healthy individuals.

Key words: postprandial glycemia, probiotic, dairy foods, functional foods

\section{INTRODUCTION}

The prevalence of diabetes type 2 (DT2) is a global health problem. Treatment costs for DT2 have increased considerably and pose a serious problem for healthcare services. Thus, the development of dietary strategies to reduce the risk of DT2 and improve the health of the population is required (Kung et al., 2018; Koutnikova et al., 2019). Although in vitro assays of $\alpha$-amylase and $\alpha$-glucosidase activity inhibition can be considered effective approaches to investigate the effect of food intake on diabetes control (Ayyash et al., 2018), evidence of efficacy depends on clinical trials (Brown et al., 2018). The frequent consumption of cow milk and dairy products has been associated with a lower risk of DT2 because of the lower postprandial glycemia (Law et al., 2017a,b), and the inclusion of probiotic cultures in dairy matrices can improve this effect. Concerning the control of DT2, postprandial glycemia is the most important parameter to be controlled, because in the long term, it can lead to serious complications, including hypertension, cardiovascular disorders, blindness, and renal failure (Patil et al., 2015).

Probiotics are living microorganisms that when administered in appropriate amounts can confer beneficial effects on the individual (Hill et al., 2014). For probiotic cultures to exert health benefits, they should be viable $\left(>10^{6}-10^{7} \mathrm{cfu} / \mathrm{g}\right)$ in the food product (Gomand et al., 2019). Lactobacillus casei 01 is a known probiotic strain associated with several health benefits, such 
as anti-hypertensive (Sperry et al., 2018), antioxidant (Vasconcelos et al., 2019), hypocholesterolemic (Sperry et al., 2018), and anticarcinogenic properties (Liu et al., 2011). Furthermore, L. casei 01 has been associated with the mitigation of inflammation caused by rheumatoid arthritis (Alipour et al., 2014). The mechanisms of action include the improvement of the serum antioxidant activity, increased concentration of bioactive peptides that have hypotensive action (Sperry et al., 2018), regulation of the immune system, improvement of disease status and inflammation (Alipour et al., 2014), decrease in serum cholesterol (Sperry et al., 2018), and anticytotoxic activity (Liu et al., 2011). However, to date, no reports exist on the anti-hyperglycemic activity of this probiotic culture in humans.

Minas Frescal cheese is considered one of the most popular cheeses in Brazil. From a technological standpoint, it has high production yield, and its high water activity provides excellent conditions for survival of probiotic strains. In addition, this cheese has a $\mathrm{pH}$ above 5.0, low sodium levels, and an absence of synthetic preservatives, and it is usually consumed in the fresh form (Sperry et al., 2018). Prato cheese is a typical Brazilian ripened cheese, obtained by the coagulation of milk with rennet or other coagulant enzymes, complemented or not by the action of specific lactic acid bacteria (Vasconcelos et al., 2019). Whey dairy beverages have been shown to display health benefits associated with the bioactive peptides, antioxidant activity, and EAA present in whey (Coutinho et al., 2019; Turkmen et al., 2019). Additionally, whey-based beverages are associated with blood glucose mitigation and decrease of appetite (Law et al., 2017a).

The effect of the consumption of probiotic dairy products on human health has been extensively studied, but the effect of the interactions between the probiotic culture and the probiotic matrix remains scarce. The structure (solid or liquid), the composition of the food matrix, as well as the manufacture and storage conditions play an important role in increasing or decreasing the probiotic viability and the health effects of the products (Gomand et al., 2019). Previous studies have evaluated the effect of consumption of probiotic-enriched dairy matrices and probiotic capsules on glucose regulation (Champagne et al., 2018). These studies have focused on yogurts as probiotic-enriched dairy products and the effects of the consumption on the fasting glucose and fasting plasma insulin of patients with DT2. To the best of our knowledge, no studies exist on the effect of different probiotic dairy matrices on postprandial glycemia in healthy individuals. In this sense, this study aimed to evaluate the effect of different probiotic dairy matrices (Minas Frescal cheese, Prato cheese, and whey dairy beverage) on anti-hyperglycemic activity in vitro ( $\alpha$-glucosidase and $\alpha$-amylase inhibitory activity) and in vivo (postprandial glycemia of healthy subjects).

\section{MATERIALS AND METHODS}

\section{Processing of Probiotic-Enriched Dairy Matrices}

Probiotic Minas Frescal Cheese. To manufacture Minas Frescal cheese, refrigerated raw milk (3.4\% lipids) was pasteurized at $72^{\circ} \mathrm{C}$ for $15 \mathrm{~s}$ and then cooled to $37^{\circ} \mathrm{C}$. Then, $0.2 \mathrm{~g} / \mathrm{L}$ calcium chloride (Labsynth, Sao Paulo, Brazil), $0.1 \mathrm{~g} / \mathrm{L}$ probiotic culture L. casei 01 (Chr. Hansen, Valinhos, Brazil, 7-8 log cfu/g), and 3 $\mathrm{g} / \mathrm{L}$ coagulant powder (Halamix power, Chr. Hansen) were added. Milk was maintained in a double-jacketed tank for $40 \mathrm{~min}$ to coagulate. The curd was cut, the whey was removed, and the grains were put in $250 \mathrm{-g}$ plastic molds. Dry salting was performed by direct addition of $0.8 \mathrm{~g}$ of $\mathrm{NaCl}$ on the cheese surface $(250 \mathrm{~g})$. Cheeses were packed and stored at $5{ }^{\circ} \mathrm{C}$ (Sperry et al., 2018).

Probiotic Prato Cheese. To manufacture probiotic Prato cheese, refrigerated raw milk (3.4\% lipids) was pasteurized at $72^{\circ} \mathrm{C}$ for $15 \mathrm{~s}$ and then cooled to $37^{\circ} \mathrm{C}$. Then, $0.1 \mathrm{~g} / \mathrm{L}$ probiotic culture L. casei 01 (Chr. Hansen, 7-8 log cfu/g) was added and milk was left to rest in the manufacturing tank for $40 \mathrm{~min}$ at $45^{\circ} \mathrm{C}$. Then, $0.2 \mathrm{~g} / \mathrm{L}$ calcium chloride (Labsynth), $3 \mathrm{~g} / \mathrm{L}$ coagulant powder (Halamix power, Chr. Hansen), and $5 \mathrm{~mL}$ of urucum dye were added. After coagulation (40 min), the curd was cut into 1-cm cubes, followed by slow and continuous stirring for $15 \mathrm{~min}$. Then, $30 \%$ of the whey was replaced by hot water at $80^{\circ} \mathrm{C}$ for a temperature increase of $1^{\circ} \mathrm{C}$ every $3 \mathrm{~min}$. The cheese grains were maintained for $40 \mathrm{~min}$ in the manufacturing tank, followed by total removal of whey and the addition of $\mathrm{NaCl}(1 \%)$. The grains were put in plastic molds and pressed at $0.1 \mathrm{MPa}$ for $15 \mathrm{~min}, 0.24 \mathrm{MPa}$ for $30 \mathrm{~min}$, and $0.31 \mathrm{MPa}$ for $90 \mathrm{~min}$. After pressing, cheeses were vacuum packed in plastic packages and stored at $10^{\circ} \mathrm{C}$ for $60 \mathrm{~d}$ for ripening (Silva et al., 2018).

Probiotic Whey-Based Beverage. For manufacture of the dairy beverage, whey powder was reconstituted in drinking water $(11 \mathrm{~g} / 100 \mathrm{~mL})$ and mixed with cooled raw milk (3.4\% fat) in whey: milk ratio of $30: 70$ $\mathrm{vol} / \mathrm{vol}$. Then, $50 \mathrm{~g} / \mathrm{L}$ sugar and $0.1 \mathrm{~g} / \mathrm{L}$ vanilla extract were added. The beverage was pasteurized at $72^{\circ} \mathrm{C}$ for $15 \mathrm{~s}$ and cooled to $37^{\circ} \mathrm{C}$. Then, $0.1 \mathrm{~g} / \mathrm{L}$ probiotic culture L. casei 01 (Chr. Hansen, 7-8 log cfu/g) was added, and the beverage was packed in sterile plastic bottles and stored at $5^{\circ} \mathrm{C}$. All dairy matrices showed probiotic counts between 7 and $8 \mathrm{log} \mathrm{cfu} / \mathrm{g}$. 


\section{Proximate Composition}

The dairy products were analyzed for the contents of moisture, proteins, and fat. The analyses were done according to the methods of AOAC International (2004).

\section{In Vitro Tests-Determination of Inhibitory Activities of $\alpha$-Glucosidase and $\alpha$-Amylase}

For each dairy matrix (Minas Frescal cheese, Prato cheese, and dairy beverage), water-soluble extracts were prepared by centrifugation at $10,000 \times g$ for 15 min at $4^{\circ} \mathrm{C}$. The supernatants were filtered through a $0.45-\mu \mathrm{m}$ filter (Mixed Cellulose Esters, EMD Millipore Corporation, Burlington, MA) and stored at $-20^{\circ} \mathrm{C}$ for further analysis (Ayyash et al., 2018).

The $\alpha$-glucosidase and $\alpha$-amylase inhibitory activities were determined according to methods proposed by Adisakwattana et al. (2012) and Lavelli et al. (2016). The $\alpha$-glucosidase inhibitory activity was determined by dissolving $100 \mu \mathrm{L}$ of $\alpha$-glucosidase (0.2 units $/ \mathrm{mL}$ ) in $100 \mu \mathrm{L}$ of phosphate buffer ( $\mathrm{pH}$ 6.8) and mixing with $150 \mu \mathrm{L}$ of water-soluble extracts. The mixture was incubated at $37^{\circ} \mathrm{C}$ for $20 \mathrm{~min}$. The reaction started with the addition of $100 \mu \mathrm{L}$ of substrate $(2.5 \mathrm{~m} M$ p-nitrophenyl $\alpha$-D-glucopyranoside). After incubation at $37^{\circ} \mathrm{C}$ for 20 min, an aliquot of $80 \mu \mathrm{L}$ of sodium carbonate solution $(0.2 \mathrm{~mol} / \mathrm{L})$ was added to stop the reaction. The amount of $p$-nitrophenol was quantified using a CMax Plus microplate reader (Promega, São Paulo, Brazil) at $405 \mathrm{~nm}$. The percent inhibition was calculated according to Equation 1:

$$
\% \text { Inhibition }=\left(1-\frac{A b s_{\text {sample }}-A b s_{\text {blank }}}{A b s_{\text {control }}}\right) \times 100,
$$

where $A b s=$ absorbance readings.

For the $\alpha$-amylase inhibitory activity, $100 \mu \mathrm{L}$ of human salivary $\alpha$-amylase (20 units $/ \mathrm{mL}$ ) was mixed with $100 \mu \mathrm{L}$ of water-soluble extracts and incubated at $37^{\circ} \mathrm{C}$ for $20 \mathrm{~min}$. The reaction started by the addition of 250 $\mu \mathrm{L}$ of starch solution $(10 \mathrm{~g} / \mathrm{L})$ in phosphate buffer $(\mathrm{pH}$ 6.8 ) at $37^{\circ} \mathrm{C}$ for $5 \mathrm{~min}$. Then, $250 \mu \mathrm{L}$ of dinitrosalicylic reagent (1\% 3,5-dinitrosalicylic acid and $12 \%$ sodium potassium tartrate in $0.4 \mathrm{M} \mathrm{NaOH}$ ) was added to stop the reaction, and the mixture was heated at $100^{\circ} \mathrm{C}$ for $10 \mathrm{~min}$. After cooling to room temperature in a coldwater bath, $2,000 \mu \mathrm{L}$ of distilled water was added to the mixture and absorbance readings were performed at $540 \mathrm{~nm}$ using a spectrophotometer. The percent inhibition was calculated according to Equation 2:

$$
\% \text { Inhibition }=\left(\frac{A b s_{\text {sample }}-A b s_{\text {control }}}{A b s_{\text {control }}}\right) \times 100,
$$

where $A b s=$ absorbance readings.

\section{Human Test}

The experimental clinical protocol for the human testing is presented in Figure 1 and consisted of a repeated measure design. Adults (male and female) were recruited at the Federal Institute of Rio de Janeiro. The inclusion criteria included healthy individuals aged between 20 and 50 years, body mass index between 18 and $25 \mathrm{~kg} / \mathrm{m}^{2}$, and regular consumption of milk or dairy products ( $>2$ servings per week). The exclusion criteria included medical events, regular use of medications, gastrointestinal disorders, food allergy, drug use, or smoking. High-intensity athletes, people using dietary supplements, pregnant women, and breast-feeding women were also excluded, as well as individuals trying to lose weight or whose weight has changed more than $5 \mathrm{~kg}$ in the last 6 mo (Kung et al., 2018). The selection of volunteers was performed in a preliminary section, using self-assessed questionnaires and measurement of weight and height of the participants.

A group of 15 healthy individuals (ages 22-46 years, male and female, with a mean body mass index of $18-24 \mathrm{~kg} / \mathrm{m}^{2}$ ) participated in the experiment. Participants consumed each of the 4 treatments coded with 3 random digits, with a 1-wk interval between the experiments. The order of consumption was randomly selected. The treatments were (1) $50 \mathrm{~g}$ of white bread $+300 \mathrm{~mL}$ of water (control); (2) $50 \mathrm{~g}$ of white bread + $50 \mathrm{~g}$ of probiotic Prato cheese; (3) $50 \mathrm{~g}$ of white bread $+300 \mathrm{~mL}$ of probiotic-enriched dairy beverage; and (4) $50 \mathrm{~g}$ of white bread $+50 \mathrm{~g}$ of probiotic Minas Frescal cheese. Before food intake, participants had fasted for 10 to $12 \mathrm{~h}$. Blood glucose levels were measured with the Accu-Chek glucometer (Roches, São Paulo, Brazil) at the following times: immediately before ingestion and at 15,30, 45, 60, 90, and 120 min after ingestion. Therefore, the postprandial study lasted $2 \mathrm{~h}$.

The area under the curve (AUC) of glucose was calculated using the trapezoidal rule to determine the reduction in glycemic response, expressed in milligrams per deciliter. Other variables were also evaluated (Corrêa et al., 2007): baseline glucose (BG), obtained at time zero; peak glucose value $(\mathbf{P G V})$, defined as the highest value above baseline observed after ingestion of the product and expressed in milligrams per deciliter; absolute increase of glucose (AIg), defined as the ab- 


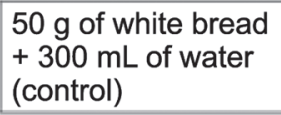

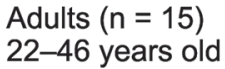
$300 \mathrm{~mL}$ of probiotic dairy beverage
$50 \mathrm{~g}$ of white bread $+50 \mathrm{~g}$ of probiotic Minas Frescal cheese
Figure 1. Experimental clinical protocol.

solute difference between the maximum value obtained after the stimulation period (PGV) and the baseline glucose (BG), expressed in milligrams per deciliter (AIg $=\mathrm{PGV}-\mathrm{BG})$; glucose incremental percentage $(\mathbf{G I P})$, defined as the ratio between the absolute increase in glucose (AIg) and the baseline value (BG), expressed as a percentage $[\mathrm{GIP}=(\mathrm{AIg} / \mathrm{BG}) \times 100]$, and glucose incremental velocity (GIV), defined as the ratio between the absolute glucose increment (AIg) and the time in minutes where the peak value was recorded, expressed in milligrams per deciliter per minute.

\section{Statistical Analysis}

The experiment (physicochemical characterization and in vitro assays) was repeated twice, and the analyses were performed in triplicate. Data were submitted to one-way ANOVA and Tukey's comparison test $(P$ $=0.05)$. For the human assays, ANOVA and Friedman test were used to compare the results between the control and the dairy matrices $(P=0.05)$. Principal component analysis was performed using a correlation matrix and aimed to obtain a 2-dimensional representation of the dairy matrices and the glycemic parameters. In addition, confidence ellipses were constructed using the bootstrapping technique. The data set consisted of a $4 \times 7$ matrix, with the lines representing the products and the columns representing the parameters analyzed (Balthazar et al., 2018). The confidence ellipses represent the multidimensional stability of a sample within the map, and 2 overlapping ellipses indicate similarity between samples (Vidal et al., 2016). Statistical analyses were performed using XLSTAT 2019.2 software (Adinsoft, Paris, France).

\section{RESULTS AND DISCUSSION}

\section{Physicochemical Characterization of Probiotic- Enriched Dairy Matrices}

Table 1 shows the physicochemical composition (moisture, protein, and lipid contents) of the probioticenriched dairy matrices. Minas Frescal cheese presented $66.2 \mathrm{~g} / 100 \mathrm{~g}$ of moisture, $15.8 \mathrm{~g} / 100 \mathrm{~g}$ of proteins, and $15.9 \mathrm{~g} / 100 \mathrm{~g}$ of lipids, corroborating previous studies (Matera et al., 2018; Sperry et al., 2018). Prato cheese presented $51.5 \mathrm{~g} / 100 \mathrm{~g}$ of moisture, $26.5 \mathrm{~g} / 100 \mathrm{~g}$ of proteins, and $36.9 \mathrm{~g} / 100 \mathrm{~g}$ of lipids, as also reported by other authors (Matera et al., 2018; Domingos et al., 2019). The whey-based beverage had $81.7 \mathrm{~g} / 100 \mathrm{~g}$ of moisture, $2.12 \mathrm{~g} / 100 \mathrm{~g}$ of proteins, and $1.4 \mathrm{~g} / 100 \mathrm{~g}$ of lipids, corroborating the findings of Janiaski et al. (2016).

Prato cheese exhibited the highest lipid and protein contents when compared with the other dairy products $(P<0.05)$ and, consequently, the lowest moisture content $(P<0.05)$. Prato cheese undergoes a more intense pressing process than Minas Frescal cheese, contributing to a greater release of whey and an increase in the

Table 1. Gross composition (mean $\pm \mathrm{SD}$ ) of the probiotic dairy matrices

\begin{tabular}{lccr}
\hline $\begin{array}{l}\text { Composition } \\
(\mathrm{g} / 100 \mathrm{~g})\end{array}$ & $\begin{array}{c}\text { Minas Frescal } \\
\text { cheese }\end{array}$ & $\begin{array}{c}\text { Prato } \\
\text { cheese }\end{array}$ & $\begin{array}{c}\text { Whey dairy } \\
\text { beverage }\end{array}$ \\
\hline Moisture & $66.2 \pm 1.2^{\mathrm{b}}$ & $51.5 \pm 0.7^{\mathrm{c}}$ & $81.7 \pm 0.2^{\mathrm{a}}$ \\
Protein & $15.8 \pm 1.1^{\mathrm{b}}$ & $26.5 \pm 0.7^{\mathrm{a}}$ & $2.12 \pm 0.4^{\mathrm{c}}$ \\
Lipids & $15.9 \pm 0.8^{\mathrm{b}}$ & $36.9 \pm 0.9^{\mathrm{a}}$ & $1.4 \pm 0.2^{\mathrm{c}}$ \\
\hline
\end{tabular}

${ }^{\mathrm{a}-\mathrm{C}}$ Means within a row with different superscripts are significantly different $(P<0.05)$ among the probiotic dairy matrices in accordance with ANOVA and Tukey's test. 
total solids content (proteins and lipids). In addition, this type of cheese is subjected to ripening; thus, the biochemical reactions can contribute to the physicochemical and sensory characteristics of the product (Domingos et al., 2019). The high moisture content of the whey-based beverage $(81.7 \mathrm{~g} / 100 \mathrm{~g})$ is related to the use of whey and milk, which present water as the main component (Turkmen et al., 2019).

\section{In Vitro Tests-Determination of $\alpha$-Glucosidase and $\alpha$-Amylase Inhibitory Activity}

Table 2 shows the in vitro $\alpha$-glucosidase and $\alpha$-amylase inhibitory activities of the different probiotic-enriched dairy matrices studied. In general, the $\alpha$-glucosidase and $\alpha$-amylase inhibitory activities were higher than $30 \%$ in all matrices, indicating that the products have hypoglycemic potential. Prato cheese presented the highest $\alpha$-amylase $(60.7 \%)$ and $\alpha$-glucosidase $(52.6 \%)$ inhibitory activities. The whey-based beverage had the second highest $\alpha$-amylase $(42.3 \%)$ and $\alpha$-glucosidase $(35.1 \%)$ inhibitory activities $(P<0.05)$. Finally, the Minas Frescal cheese presented the lowest enzyme inhibitory activity $(P<0.05)$.

The presence of bioactive peptides, particularly those with smaller chain lengths, is associated with $\alpha$-glucosidase and $\alpha$-amylase inhibitory activity (Ayyash et al., 2018). Peptides are produced in cheese by a combination of factors, such as the presence of chymosin, endogenous proteinases in milk (mainly plasmin), and proteolytic enzymes of probiotics and lactic acid cultures, as well as the pretreatment of milk, scalding during the cheese-making, and ripening period. Primary caseins are cleaved by chymosin and endogenous proteinases, whereas the secondary cleavage is catalyzed by proteinases and several peptidases of the cultures (Uenishi et al., 2012). Prato cheese has a long ripening period, resulting in a higher formation of bioactive peptides in response to casein proteolysis, which is directly related to the $\alpha$-glucosidase and $\alpha$-amylase inhibitory activities (Cruz et al., 2009; Pessione and Cirrincione, 2016). The thermal processing of whey-based products, such as dairy beverages, may result in partial protein denaturation with a consequent increase in bioactive peptides. These compounds can be considered functional compounds, with health benefits, modulating different biological and physiological properties (Coutinho et al., 2019). In addition, some probiotic strains may have the ability to release bioactive peptides from milk caseins (Pessione and Cirrincione, 2016).

The results of the in vitro assays indicated that Prato cheese had higher in vitro anti-hyperglycemic
Table 2. Inhibitory activities (mean $\pm \mathrm{SD}$ ) of $\alpha$-glycosidase and $\alpha$-amylase of probiotic dairy matrices

\begin{tabular}{lccc}
\hline Item & $\begin{array}{c}\text { Minas Frescal } \\
\text { cheese }\end{array}$ & $\begin{array}{c}\text { Prato } \\
\text { cheese }\end{array}$ & $\begin{array}{c}\text { Whey dairy } \\
\text { beverage }\end{array}$ \\
\hline$\alpha$-Amylase (\%) & $37.9 \pm 0.3^{\mathrm{c}}$ & $60.7 \pm 0.5^{\mathrm{a}}$ & $42.3 \pm 0.1^{\mathrm{b}}$ \\
$\alpha$-Glycosidase (\%) & $30.0 \pm 0.4^{\mathrm{c}}$ & $52.6 \pm 0.5^{\mathrm{a}}$ & $35.1 \pm 0.3^{\mathrm{b}}$ \\
\hline
\end{tabular}

$\overline{{ }^{a c} \text { Means within a row with different superscripts are significantly dif- }}$ ferent $(P<0.05)$ among the probiotic dairy matrices. Data were submitted to ANOVA and Tukey's test.

activity because it exhibited a higher $\alpha$-glucosidase and $\alpha$-amylase inhibitory activity, followed by the wheybased beverage and Minas Frescal cheese. The results indicate that the cheese ripening allowed the further development of bioactive peptides related to the inhibition effects on the enzymes. The use of whey in the manufacture of dairy products, such as dairy beverages, also contributed to the effects observed. Santiago-López et al. (2018) reported an increase in proteolytic activity during cheese ripening, with consequent increase in the number of bioactive peptides. Ayyash et al. (2018) reported that cheeses present high $\alpha$-glucosidase and $\alpha$-amylase inhibitory activities, probably because of the presence of bioactive peptides. Furthermore, SantiagoLópez et al. (2018) also reported that the heat treatment of milk proteins can affect the concentration and specific sequence of bioactive peptides.

\section{Clinical Study}

Figure 2 shows the blood glucose levels before and after the ingestion of probiotic-enriched dairy matrices, and Table 3 shows the results of the different parameters evaluated after the ingestion of different matrices. Similar results were observed for basal glucose (before consumption, GB; $\cong 90 \mathrm{mg} / \mathrm{dL}$ ) for the control, Prato cheese, and dairy beverage $(P>0.05)$, whereas Minas Frescal cheese exhibited higher levels $(\cong 100 \mathrm{mg} / \mathrm{dL} ; P$ $<0.05)$. The consumption of Minas Frescal cheese led to a higher blood glucose level for all times evaluated $(0,15,30,45,60,90$, and $120 \mathrm{~min})$ when compared with the control $(P<0.05)$. The consumption of dairy beverage resulted in a higher blood glucose level only after 15 and 30 min of ingestion $(P<0.05)$, whereas the consumption of Prato cheese resulted in a lower blood glucose level after 45, 60, and 90 min of ingestion $(P<0.05)$.

The consumption of bread alone (control) resulted in an increase in the blood glucose levels up to $109 \mathrm{mg} /$ dL within $45 \mathrm{~min}$ after ingestion (increase of $19 \mathrm{mg} /$ $\mathrm{dL}$ ), with a subsequent reduction to initial values (90 $\mathrm{m} / \mathrm{dL}$ ) after $120 \mathrm{~min}$ (Figure 2). In fact, according to Gross, Ferreira, and Oliveira (2003), the blood sugar 


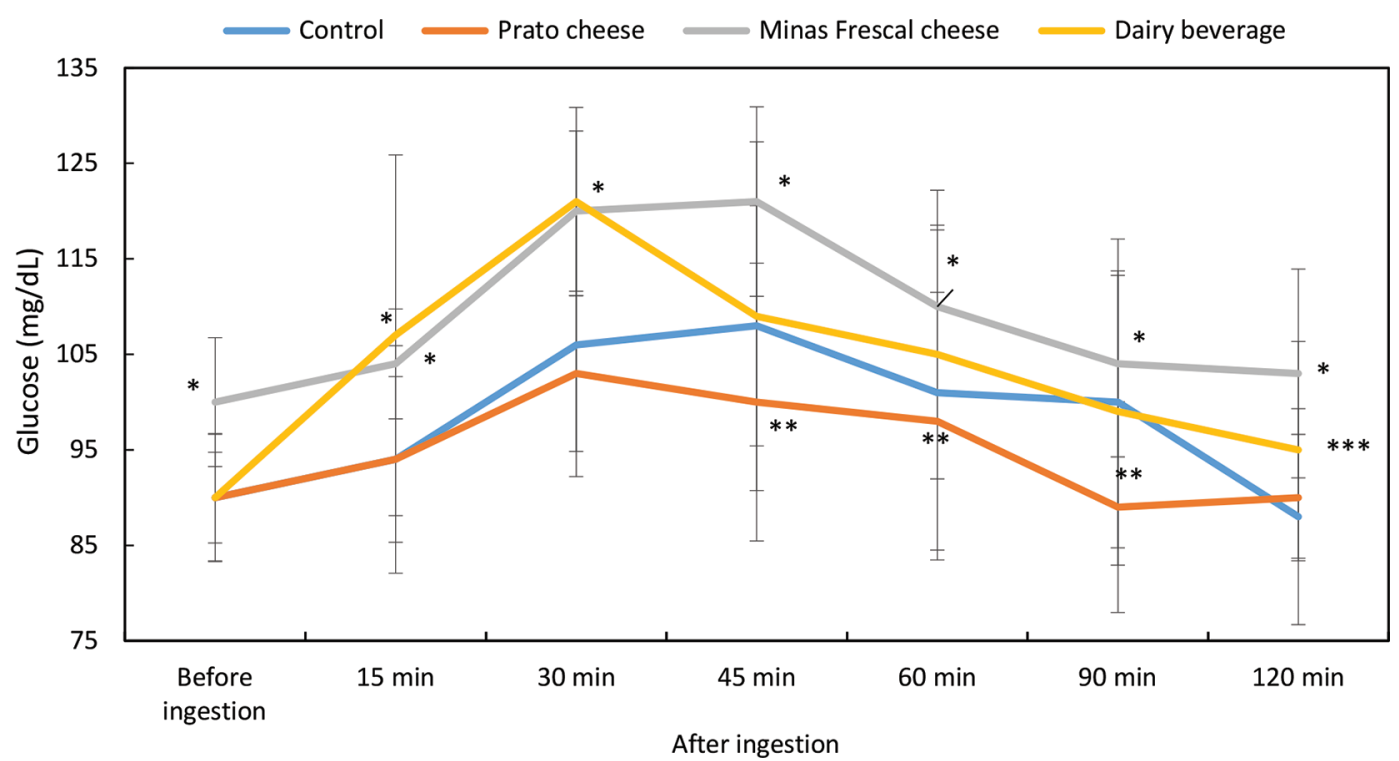

Figure 2. Blood glucose levels before and after ingestion of probiotic dairy matrices. The error bars represent the standard deviation $(\mathrm{n}=$ 15). Data were submitted to ANOVA and Friedman test aiming to compare the results between the control and the dairy matrices. Asterisks mean the Minas Frescal cheese, Prato cheese, or dairy beverage glucose level is significantly different from that of the control at the $* P<0.05$, ** $P<0.01$, or $* * * P<0.001$ level.

levels increase after 10 min of the food intake, with the maximum values at 60 min after ingestion, reaching the basal levels within 2 to $3 \mathrm{~h}$. The glycemic load depends on the amount of carbohydrates, type, and composition of food, and time of food intake.

The consumption of Minas Frescal cheese resulted in a similar trend compared with the control, with an increase in the blood glucose levels up to $120 \mathrm{mg} / \mathrm{dL}$ at $30 \mathrm{~min}$ after ingestion (increase of $20 \mathrm{mg} / \mathrm{dL}$ ), with a subsequent reduction to initial values $(103 \mathrm{mg} / \mathrm{dL})$ after 120 min. The consumption of Minas Frescal cheese did not affect the other glycemic indices PGV, AIg, GIP, and GIV $(P>0.05$, Table 3$)$, with an increase in AUC and BG $(P<0.05)$, as previously reported. Thus, the results indicate no changes in the glycemic indices of healthy individuals after consumption of Minas Frescal cheese + bread, when compared with the consumption of bread alone.

The consumption of the whey-based beverage resulted in an accelerated increase in the glycemic levels $(30 \mathrm{mg} / \mathrm{dL}$ in $30 \mathrm{~min})$ when compared with the result observed after the consumption of bread alone (control) and both cheeses $(19-20 \mathrm{mg} / \mathrm{dL}, P<0.05$, Figure 2). Thus, GIV increased and hyperglycemic peak decreased $(P<0.05$, Table 3). The consumption of the wheybased beverage led to an increase in GIV because of the presence of sucrose in its composition $(50 \mathrm{~g} / \mathrm{L})$, with a consequent decrease in the hyperglycemic peak. After

Table 3. Effects of consumption of probiotic dairy matrices on postprandial glycemia in healthy individuals ${ }^{1}$

\begin{tabular}{lcccc}
\hline Item $^{2}$ & $\begin{array}{c}\text { Minas Frescal } \\
\text { cheese }\end{array}$ & $\begin{array}{c}\text { Prato } \\
\text { cheese }\end{array}$ & $\begin{array}{c}\text { Whey dairy } \\
\text { beverage }\end{array}$ & Control \\
\hline PGV & $125.3 \pm 8.9^{\mathrm{a}}$ & $110.8 \pm 8.5^{\mathrm{b}}$ & $126.6 \pm 14.4^{\mathrm{a}}$ & $118.3 \pm 14.7^{\mathrm{ab}}$ \\
$\mathrm{AIg}$ & $25.7 \pm 13.0^{\mathrm{b}}$ & $20.8 \pm 10.7^{\mathrm{b}}$ & $36.6 \pm 13.8^{\mathrm{a}}$ & $28.4 \pm 16.2^{\mathrm{ab}}$ \\
GIP & $26.5 \pm 14 .^{\mathrm{b}}$ & $23.8 \pm 134^{\mathrm{b}}$ & $40.8 \pm 15.3^{\mathrm{a}}$ & $32.3 \pm 19.9^{\mathrm{ab}}$ \\
GIV & $0.7 \pm 0.4^{\mathrm{b}}$ & $0.6 \pm 0.3^{\mathrm{b}}$ & $1.4 \pm 0.8^{\mathrm{a}}$ & $0.7 \pm 0.4^{\mathrm{b}}$ \\
AUC & $13,112 \pm 708^{\mathrm{a}}$ & $11,416 \pm 981^{\mathrm{c}}$ & $12,518 \pm 1,096^{\mathrm{ab}}$ & $11,949 \pm 1,010^{\mathrm{bc}}$ \\
GB & $99.7 \pm 6.7^{\mathrm{a}}$ & $90.0 \pm 6.7^{\mathrm{b}}$ & $90.0 \pm 4.7^{\mathrm{b}}$ & $89.9 \pm 6.6^{\mathrm{b}}$ \\
HP & $40.0 \pm 10.8^{\mathrm{ab}}$ & $40.0 \pm 12.2^{\mathrm{ab}}$ & $31.0 \pm 10.5^{\mathrm{b}}$ & $51.0 \pm 23.2^{\mathrm{a}}$ \\
\hline
\end{tabular}

${ }^{a-c}$ Means with different superscripts are significantly different $(P<0.05)$ among the probiotic dairy matrices. Data were submitted to ANOVA and Tukey's comparison test $(P=0.05)$.

${ }^{1}$ Results are expressed in mean $\pm \mathrm{SD}(\mathrm{n}=15)$.

${ }^{2} \mathrm{PGV}=$ maximum glucose value; $\mathrm{AIg}=$ maximum glucose increase; $\mathrm{GIP}=$ incremental glucose percentage; $\mathrm{GIV}=$ incremental glucose rate; $\mathrm{AUC}=$ area under the curve; $\mathrm{GB}=$ basal glucose; $\mathrm{HP}=$ peak blood glucose time. 
reaching the hyperglycemic peak, glycemic levels decreased, with a final value of $95 \mathrm{mg} / \mathrm{dL}$, slightly higher than the initial values $(90 \mathrm{mg} / \mathrm{dL}$, Figure 2$)$. It is worth emphasizing that the whey-based beverage exhibited a similar effect on lowering the blood glucose levels when compared with the consumption of bread alone, suggesting that this dairy matrix has the ability to control blood glucose. These results corroborate those observed for $\alpha$-glucosidase and $\alpha$-amylase inhibitory activity in vitro (Table 2). Kung et al. (2018) reported that whey protein is an insulinemic agent, with a positive effect on the reduction of glycemia when compared with casein. Pessione and Cirrincione (2016) reported that the proteolytic activity of probiotic cultures on whey proteins may result in the appearance of peptides that enhance glucose absorption, thus controlling hyperglycemia.

The consumption of Prato cheese led to an increase in blood glucose levels up to $103 \mathrm{mg} / \mathrm{dL}$ in $30 \mathrm{~min}$ (increase of $13 \mathrm{mg} / \mathrm{dL}$ ), with a subsequent reduction to initial values $(90 \mathrm{mg} / \mathrm{dL}$ ) after 120 min (Figure 2). In addition, the consumption of Prato cheese did not change the glycemic indices (PGV, AIg, GIP, GIV, and AUC). Therefore, the consumption of Prato cheese resulted in a lower increase in glycemia $(13 \mathrm{mg} / \mathrm{dL})$ when compared with the consumption of bread alone $(19 \mathrm{mg} /$ $\mathrm{dL}$ ), demonstrating the role of this dairy product in the reduction of postprandial blood glucose levels. These results corroborate those observed for $\alpha$-glucosidase and $\alpha$-amylase inhibitory activity in vitro (Table 2 ) and may be associated with the presence of a greater number of bioactive peptides, as well as the chemical composition of this product. Kung et al. (2018) reported that products with higher contents of proteins have the ability to attenuate the increase in blood glucose within 15 to 90 min after food intake. Geurts et al. (2012) observed that the ripening time of the cheeses under study $(0,15$, or $35 \mathrm{~d})$ had a significant influence on the physiological characteristics of obese and diabetic mice. Cheeses with $35 \mathrm{~d}$ of ripening significantly improved glucose regulation without affecting BW, food intake, and fat mass. The authors reported that the production of metabolites by lactic or probiotic cultures and the proteolysis events are related to the ripening time, which may have contributed to improve host metabolism. Similar results were found in the present study after consumption of $60-\mathrm{d}$ Prato cheeses by health individuals.

The probiotic addition to the dairy matrices may have contributed to the findings of the present study. Probiotic cultures are able to modify gut microbiota, which stimulates glucose absorption by the production of insulinotropic polypeptides and glucagon-like peptides (Nikbakht et al., 2018). Furthermore, the probiotic cultures located in intestinal epithelium can use glucose and reduce the intestinal glucose absorption, as well as inhibit the production of proinflammatory cytokines that are responsible for pancreatic cell destruction and reduced insulin production (Nikbakht et al., 2018). Although all probiotic dairy matrices exhibited similar probiotic counts $(7-8 \log \mathrm{cfu} / \mathrm{g})$, the health effect is dependent on the dairy matrix and the probiotic survival through the gastrointestinal tract.

Figure 3 shows the principal component analysis of data from the in vivo trial. Principal component 1 explained $59.57 \%$ of the data variability, whereas component 2 explained $29.85 \%$, totaling $89.42 \%$ of explained variability. Minas Frescal cheese was strongly associated with high glucose values at time zero (BG), AUC, and PGV. The whey-based beverage was correlated with AIg, GIV, and GIP. The control and Prato cheese were associated with the hyperglycemic peak.

In principal component analysis, the confidence ellipses allowed better observation of data on 2-dimensional projection. Well-separated ellipses indicate complete differentiation of samples, whereas the samples that strongly overlap are associated with products that cannot be differentiated (Pereira et al., 2019). The ellipses of control, Prato cheese, and whey-based beverage were overlapped, indicating that the consumption of these dairy matrices has an effect on blood glucose similar to the consumption of bread alone.

This study has some limitations. The menstrual cycle of the women was not controlled, and the human tests were conducted with healthy individuals, not considering the effect of sex on the glycemic indexes. Glucose metabolism is affected by menstrual cycle phase; the glucose rates of appearance and disappearance may be lower during the luteal phase (high progesteroneto-estrogen ratio) when compared with the follicular phase (high estrogen-to-progesterone ratio; Varlamov et al., 2015). Furthermore, glucose effectiveness and glucose appearance rates are generally higher in women (Varlamov et al., 2015).

\section{CONCLUSIONS}

Prato cheese was the dairy matrix with the best results, presenting a better nutritional composition (higher lipid and protein contents) and greater antihyperglycemic activity in vitro (greater $\alpha$-amylase and $\alpha$-glucosidase inhibitory activity) and in vivo [lower increase in postprandial glycemia and maintenance of the other glycemic indexes (PGV, AIg, GIP, GIV, AUC, BG, hyperglycemic peak)] in healthy subjects. A multivariate association was observed between the in vitro and in vivo data; the products with higher $\alpha$-glucosidase and $\alpha$-amylase inhibitory activities (in vitro) resulted in lower postprandial glycemia in the 

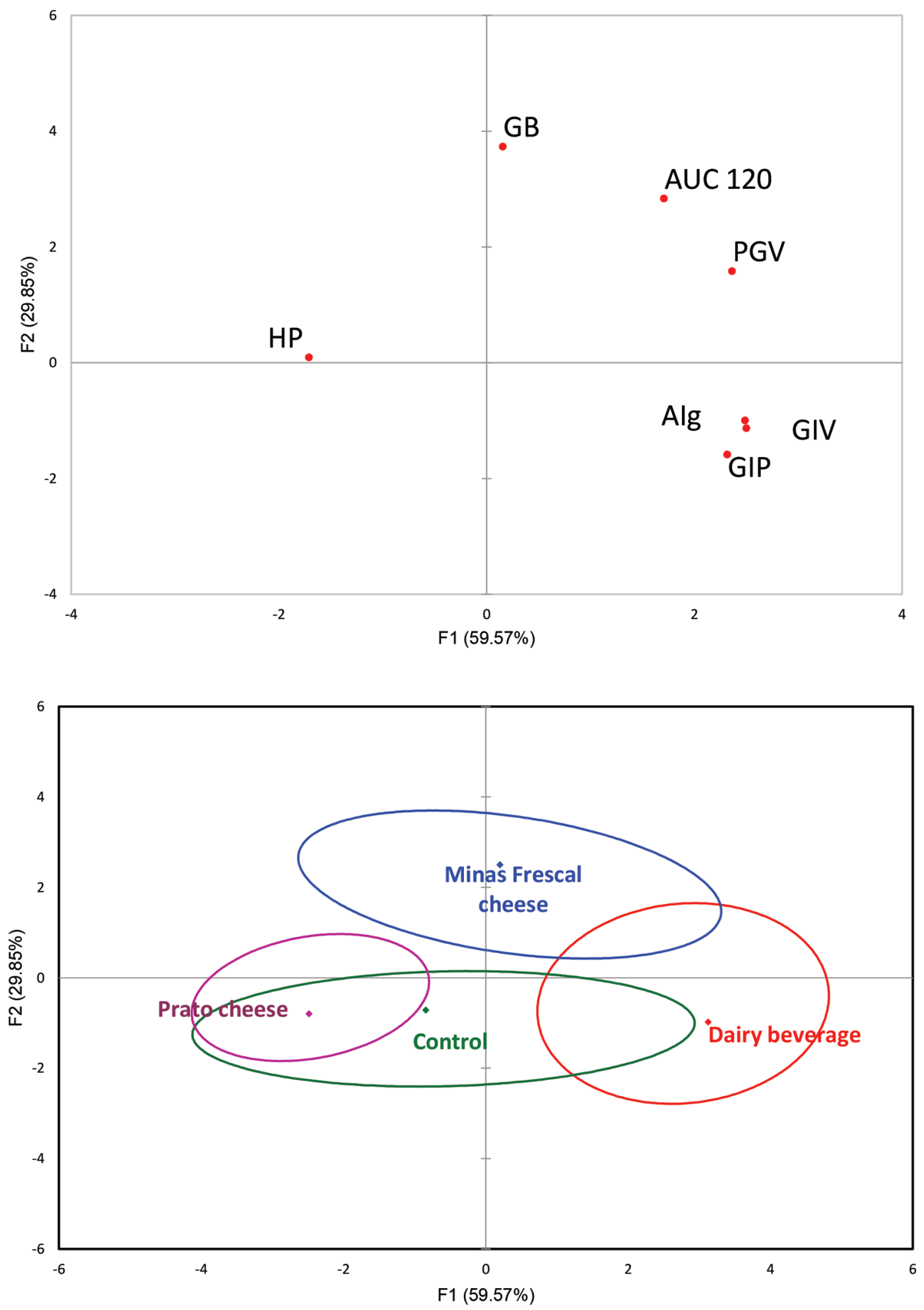

Figure 3. Representation of the samples and attributes in the first and second dimensions (F1 or F2) of the principal component analysis in the correlation matrix of the mean scores of the analytical attributes of the postprandial glycemia reduction analysis of 3 probiotic and control dairy matrices. $\mathrm{GB}=$ glucose at time zero; $\mathrm{HP}=$ hyperglycemic peak; PGV = maximum glucose value; AIg = maximum glucose increase; GIP $=$ incremental glucose percentage; GIV = incremental glucose rate; and AUC $120=$ area under the curve. 
volunteers. This study is the first to evaluate the effect of different dairy matrices on anti-hyperglycemic activity. Overall, experimental results showed that dairy matrix plays an important role in the anti-hyperglycemic index, and the consumption of ripened cheese or a whey dairy beverage is recommended to possibly decrease postprandial glycaemia.

\section{ACKNOWLEDGMENTS}

The authors are grateful to Fundação de Amparo à Pesquisa do Estado do Rio de Janeiro (FAPERJ, Brazil), Coordenação de Aperfeiçoamento de Pessoal de Nível Superior (CAPES, Brazil), CNPq (Conselho Nacional de Desenvolvimento Científico e Tecnológico, Brazil), and Instituto Federal do Rio de Janeiro (IFRJ, Brazil) for the financial support.

\section{REFERENCES}

Adisakwattana, S., T. Ruengsamran, P. Kampa, and W. Sompong. 2012. In vitro inhibitory effects of plant-based foods and their combinations on intestinal $\alpha$-glucosidase and pancreatic $\alpha$-amylase. BMC Complement. Altern. Med. 12:110. https://doi.org/10.1186/ 1472-6882-12-110.

Alipour, B., A. Homayouni-Rad, E. Vaghef-Mehrabany, S. K. Sharif, L. Vaghef-Mehrabany, M. Asghari-Jafarabadi, M. R. Nakhjavani, and J. Mohtadi-Nia. 2014. Effects of Lactobacillus casei supplementation on disease activity and inflammatory cytokines in rheumatoid arthritis patients: A randomized double-blind clinical trial. Int. J. Rheum. Dis. 17:519-527.

AOAC International. 2004. Official Methods of Analysis. 15th ed. AOAC Int., Washington, DC.

Ayyash, M., A. K. Al-Nuaimi, S. Al-Mahadin, and S. Q. Liu. 2018. In vitro investigation of anticancer and ACE-inhibiting activity, $\alpha$-amylase and $\alpha$-glucosidase inhibition, and antioxidant activity of camel milk fermented with camel milk probiotic: A comparative study with fermented bovine milk. Food Chem. 239:588-597. https://doi.org/10.1016/j.foodchem.2017.06.149.

Balthazar, C. F., A. Santillo, L. Figliola, H. L. Silva, E. A. Esmerino, M. Q. Freitas, A. G. Cruz, and M. Albenzio. 2018. Sensory evaluation of a novel prebiotic sheep milk strawberry beverage. Lebensm. Wiss. Technol. 98:94-98. https://doi.org/10.1016/j.lwt.2018 .08.017.

Brown, L., S. P. Caligiuri, D. Brown, and G. N. Pierce. 2018. Clinical trials using functional foods provide unique challenges. J. Funct. Foods 45:233-238. https://doi.org/10.1016/j.jff.2018.01.024.

Champagne, C. P., A. G. Cruz, and M. Daga. 2018. Strategies to improve the functionality of probiotics in supplements and foods. Curr. Opin. Food Sci. 22:160-166.

Corrêa, F. H., V. G. Nogueira, M. D. F. Bevilácqua, and M. D. B. Gomes. 2007. Insulin resistance and secretion assessment across a range of glucose tolerance from normal individuals through diabetes. Arq. Bras. Endocrinol. Metabol 51:1498-1505.

Coutinho, N. M., M. R. Silveira, L. M. Fernandes, J. Moraes, T. C. Pimentel, M. Q. Freitas, M. C. Silva, R. S. L. Raices, C. S. Ranadheera, F. O. Borges, R. P. C. Neto, M. I. B. Tavares, F. A. N. Fernandes, T. V. Fonteles, F. Nazzaro, S. Rodrigues, and A. G. Cruz. 2019. Processing chocolate milk drink by low-pressure cold plasma technology. Food Chem. 278:276-283. https://doi.org/10 $.1016 /$ j.foodchem.2018.11.061.

Cruz, A. G., F. C. A. Buriti, C. H. B. de Souza, J. A. F. Faria, and S. M. I. Saad. 2009. Probiotic cheese: Health benefits, technological and stability aspects. Trends Food Sci. Technol. 20:344-354. https: //doi.org/10.1016/j.tifs.2009.05.001.
Domingos, L. D., H. A. L. de Souza, L. R. B. Mariutti, M. T. Benassi, N. Bragagnolo, and W. H. Viotto. 2019. Fat reduction and whey protein concentrate addition alter the concentration of volatile compounds during Prato cheese ripening. Food Res. Int. 119:793804. https://doi.org/10.1016/j.foodres.2018.10.062.

Gomand, F., F. Borges, J. Burgain, J. Guerin, A.-M. Revol-Junelles, and C. Gaiani. 2019. Food matrix design for effective lactic acid bacteria delivery. Annu. Rev. Food Sci. Technol. 10:285-310. https: //doi.org/10.1146/annurev-food-032818-121140.

Gross, J. L., S. R. Ferreira, and J. E. D. Oliveira. 2003. Glicemia pósprandial. Arq. Bras. Endocrinol. Metabol 47:728-738. https://doi .org/10.1590/S0004-27302003000600017.

Geurts, L., A. Everard, P. Le Ruyet, M. N. Delzenne, and P. D. Cani. 2012. Ripened dairy products differentially affect hepatic lipid content and adipose tissue oxidative stress markers in obese and type 2 diabetic mice. J. Agric. Food Chem. 60:2063-2068.

Hill, C., F. Guarner, G. Reid, G. R. Gibson, D. J. Merenstein, B. Pot, L. Morelli, R. B. Canani, H. J. Flint, S. Salminen, P. C. Calder, and M. E. Sanders. 2014. The International Scientific Association for Probiotics and Prebiotics consensus statement on the scope and appropriate use of the term probiotic. Nat. Rev. Gastroenterol. Hepatol. 11:506-514. https://doi.org/10.1038/nrgastro.2014 66 .

Janiaski, D. R., T. C. Pimentel, A. G. Cruz, and S. H. Prudencio. 2016. Strawberry-flavored yogurts and whey beverages: What is the sensory profile of the ideal product? J. Dairy Sci. 99:52735283. https://doi.org/10.3168/jds.2015-10097.

Koutnikova, H., B. Genser, M. Monteiro-Sepulveda, J. M. Faurie, S. Rizkalla, J. Schrezenmeir, and K. Clément. 2019. Impact of bacterial probiotics on obesity, diabetes and non-alcoholic fatty liver disease related variables: A systematic review and meta-analysis of randomised controlled trials. BMJ Open 9:e017995. https://doi .org/10.1136/bmjopen-2017-017995.

Kung, B., G. H. Anderson, S. Paré, A. J. Tucker, S. Vien, A. J. Wright, and H. D. Goff. 2018. Effect of milk protein intake and caseinto-whey ratio in breakfast meals on postprandial glucose, satiety ratings, and subsequent meal intake. J. Dairy Sci. 101:8688-8701. https://doi.org/10.3168/jds.2018-14419.

Lavelli, V., P. S. C. Sri Harsha, P. Ferranti, A. Scarafoni, and S. Iametti. 2016. Grape skin phenolics as inhibitors of mammalian $\alpha$-glucosidase and $\alpha$-amylase - Effect of food matrix and processing on efficacy. Food Funct. 7:1655-1663. https://doi.org/10.1039/ $\mathrm{C} 6 \mathrm{FO} 00073 \mathrm{H}$

Law, M., P. S. P. Huot, Y. T. Lee, S. Vien, B. L. Luhovyy, and G. H. Anderson. 2017a. The effect of dairy and non-dairy beverages consumed with high glycemic cereal on subjective appetite, food intake and postprandial glycemia in young adults. Appl. Physiol. Nutr. Metab. 42:1201-1209. https://doi.org/10.1139/apnm-2017 -0135 .

Law, M., Y. T. Lee, S. Vien, B. L. Luhovyy, and G. H. Anderson. 2017b. The effect of dairy products consumed with high glycemic carbohydrate on subjective appetite, food intake and postprandial glycemia in older adults. Appl. Physiol. Nutr. Metab. 42:12101216. https://doi.org/10.1139/apnm-2017-0210.

Liu, C. T., F. J. Chu, C. C. Chou, and R. C. Yu. 2011. Antiproliferative and anticytotoxic effects of cell fractions and exopolysaccharides from Lactobacillus casei 01. Mutat. Res. Genet. Toxicol. Environ. Mutagen. 721:157-162. https://doi.org/10.1016/j.mrgentox .2011.01.005.

Matera, J., A. S. Luna, D. B. Batista, T. C. Pimentel, J. Moraes, B. A. Kamimura, M. V. S. Ferreira, H. L. A. Silva, S. P. Mathias, E. A. Esmerino, M. Q. Freitas, R. S. L. Raices, S. L. Quitério, A. S. Sant'Ana, M. C. Silva, and A. G. Cruz. 2018. Brazilian cheeses: A survey covering physicochemical characteristics, mineral content, fatty acid profile and volatile compounds. Food Res. Int. 108:18 26. https://doi.org/10.1016/j.foodres.2018.03.014.

Nikbakht, E., S. Khalesi, I. Singh, L. T. Williams, N. P. West, and N. Colson. 2018. Effect of probiotics and synbiotics on blood glucose: A systematic review and meta-analysis of controlled trials. Eur. J. Nutr. 57:95-106. 
Patil, P., S. Mandal, S. K. Tomar, and S. Anand. 2015. Food proteinderived bioactive peptides in management of type 2 diabetes. Eur. J. Nutr. 54:863-880.

Pereira, G. S., A. R. Honorio, B. R. Gasparetto, C. M. Lopes, D. C. D. Lima, and A. A. Tribst. 2019. Influence of information received by the consumer on the sensory perception of processed orange juice. J. Sens. Stud. 34:e12497. https://doi.org/10.1111/joss.12497.

Pessione, E., and S. Cirrincione. 2016. Bioactive molecules released in food by lactic acid bacteria: Encrypted peptides and biogenic amines. Front. Microbiol. 7:876. https://doi.org/10.3389/fmicb .2016 .00876 .

Santiago-López, L., J. E. Agular-Toalá, A. Hernández-Mendoza, B. Vallejo-Cordoba, A. M. Liceaga, and A. F. González-Córdova. 2018. Invited review: Bioactive compounds produced during cheese ripening and health effects associated with aged cheese consumption. J. Dairy Sci. 101:3742-3757.

Silva, H. L. A., C. F. Balthazar, R. S. Rocha, J. Moraes, E. A. Esmerino, M. C. Silva, R. S. L. Raices, T. C. Pimentel, M. Q. Freitas, and A. G. Cruz. 2018. Sodium reduction and flavor enhancers addition: Is there an impact on the availability of minerals from probiotic Prato cheese? LWT 93:287-292. https://doi.org/10.1016/j .lwt.2018.03.053.

Sperry, M. F., H. L. A. Silva, C. F. Balthazar, E. A. Esmerino, S. Verruck, E. S. Prudencio, R. P. C. Neto, M. I. B. Tavares, J. C. Peixoto, F. Nazzaro, R. S. Rocha, J. Moraes, A. S. G. Gomes, R. S. L. Raices, M. C. Silva, D. Granato, T. C. Pimentel, M. Q. Freitas, and A. G. Cruz. 2018. Probiotic Minas Frescal cheese added with $L$. casei 01: Physicochemical and bioactivity characterization and effects on hematological/biochemical parameters of hypertensive overweighted women-A randomized double-blind pilot trial J. Funct. Foods 45:435-443. https://doi.org/10.1016/j.jff.2018.04 .015 .

Turkmen, N., C. Akal, and B. Özer. 2019. Probiotic dairy-based beverages: A review. J. Funct. Foods 53:62-75. https://doi.org/10.1016/ j.jff.2018.12.004.

Uenishi, H., T. Kabuki, Y. Seto, A. Serizawa, and H. Nakajima. 2012. Isolation and identification of casein-derived dipeptidyl-peptidase 4 (DPP-4)-inhibitory peptide LPQNIPPL from gouda-type cheese and its effect on plasma glucose in rats. Int. Dairy J. 22:24-30. https://doi.org/10.1016/j.idairyj.2011.08.002.

Varlamov, O., C. L. Bethea, and C. T. Roberts Jr.. 2015. Sex-specific differences in lipid and glucose metabolism. Front. Endocrinol. $5: 24$.

Vasconcelos, F. M., H. L. A. Silva, S. M. Poso, M. V. Barroso, M. Lanzetti, R. S. Rocha, J. S. Graça, E. A. Esmerino, M. Q. Freitas, M. C. Silva, R. S. L. Raices, D. Granato, T. C. Pimentel, A. S. Sant'Ana, A. G. Cruz, and S. S. Valença. 2019. Probiotic Prato cheese attenuates cigarette smoke-induced injuries in mice. Food Res. Int. 123:697-703. https://doi.org/10.1016/j.foodres.2019.06 .001 .

Vidal, L., S. R. Jaeger, L. Antúnez, A. Giménez, and G. Ares. 2016. Product spaces derived from projective mapping and CATA questions: Influence of replicated assessments and increased number of study participants. J. Sens. Stud. 31:373-381. https://doi.org/10 $.1111 /$ joss. 12220 